\title{
IMPLEMENTASI MUATAN LOKAL UNTUK PENDIDIKAN KHUSUS DI BANGKA BELITUNG
}

\author{
Sapto Aji Wirantho ${ }^{1}$, Farah Arriani ${ }^{2}$, Soraya Ramli ${ }^{3}$ \\ 1,2 Pusat Kurikulum dan Perbukuan, ${ }^{3}$ STBA LIA Jakarta \\ ${ }^{1}$ saptoajiwirantho@gmail.com, ${ }^{2}$ faraharriani@gmail.com, \\ ${ }^{3}$ sorayahermawan21@gmail.com
}

\begin{abstract}
Abstrak
Indonesia memiliki kekayaan sumber daya alam, sumber daya manusia dan keragaman budaya daerah. Budaya daerah menjadi aset daerah sekaligus aset nasional. Berbagai upaya dilakukan untuk mempertahankan budaya daerah, salah satunya melalui pendidikan. Budaya daerah masuk ke dalam kurikulum melalui muatan lokal (Mulok). Peran besar pemerintah daerah khususnya bidang pendidikan yaitu mengembangkan Mulok di semua satuan pendidikan. Namun, memperkenalkan mulok budaya daerah pada anak berkebutuhan khusus merupakan sesuatu tantangan, karena anak berkebutuhan khusus (ABK) memiliki karakteristik yang unik. Jika budaya dapat dikembangkan dalam mulok di pendidikan khusus, niscaya pendidikan di luar pendidikan khusus akan lebih mudah ditangani. Karena itu, penelitian ini berupaya menggali implementasi muatan lokal yang diterapkan pada satuan pendidikan khusus di Bangka Belitung. Penelitian dilakukan dengan metode campuran, kuantitatif dan kualitatif untuk mendapatkan gambaran yang lebih rinci. Data diperoleh dengan metode survei, FGD, dan pengamatan kelas terhadap 22 guru mulok yang mewakili sembilan kabupaten/kota. Hasil penelitian menyimpulkan bahwa Muatan lokal diberikan ke anak berkebutuhan khusus sebagai bagian dari kehidupan mereka agar terbiasa dilakukan/dipraktikkan dalam kehidupan sehari-hari dan menjadi keterampilan kehidupan bagi mereka di sekolah, rumah, dan masyarakat dengan pembiasaan agar mereka mengenal dan terbiasa melakukan/mempraktikkan di sekolah, rumah, dan masyarakat.
\end{abstract}

Kata Kunci: Pendidikan; Kurikulum; Muatan Lokal; Pendidikan Khusus; Anak Berkebutuhan

Khusus (ABK).

\section{Abstract}

Indonesia has a wealth of natural resources, human resources and regional cultural diversity. Regional culture is a regional asset as well as a national asset. Various attempts were made to maintain the regional culture, one of which is through education. Regional culture applied in the curriculum through local content (Mulok). The big role of the regional government, especially in the education sector, is to develop Mulok in all education units. However, introducing regional culture mulok to children with special needs is a challenge, because children with special needs $(A B K)$ have unique characteristics. If culture can be developed in mulok in special education, 


\section{Edutainment: Jurnal Ilmu Pendidikan dan Kependidikan}

Volume 8 Nomor 1 Edisi Januari - Juni 2020

surely education outside of special education will be easier to handle. The study was conducted using mixed method, quantitative and qualitative, to get more comprehensive picture. Data were obtained by survei method, FGD, and classroom observations of 22 mulok teachers representing nine districts / cities. The results of the study concluded that Mulok needs to be given to ABK through habituation in order that they know and be accustomed to doing/practicing in schools, homes, and the community.

Keywords: Education; Curriculum; Local Content; Special Education; Children with Special Needs.

\section{PENDAHULUAN}

Indonesia merupakan negara dengan keanekaragaman adat istiadat, tata cara, bahasa, kesenian, kerajinan, keterampilan daerah. Keanekaragaman ini harus dilestarikan oleh semua orang. Namun, perkembangan situasi budaya di Indonesia menimbulkan kegelisahan. Hasil penelitian Wirantho (2008) menyatakan bahwa kegelisahan muncul ditengarai oleh 1) bahasa daerah tidak menjadi bahasa percakapan sehari - hari, 2) anak tidak bermain dan mengenal permainan tradisional, 3) banyak masyarakat yang tidak mengenal seni budaya khas daerah.

Oleh karena itu, penguatan budaya daerah perlu segera dilakukan dengan pengenalan lingkungan, sosial, dan budaya kepada semua orang, khususnya anak - anak yang menjadi peserta didik, sehingga mereka dapat lebih akrab dengan lingkungannya. Salah satu hal yang dilakukan oleh pemerintah yaitu melalui pendidikan. Undang - Undang No. 20, 2003 menyatakan bahwa pendidikan merupakan usaha sadar dan terencana untuk mewujudkan suasana belajar dan proses pembelajaran agar peserta didik secara aktif mengembangkan potensi dirinya untuk memiliki kekuatan spiritual keagamaan, pengendalian diri, kepribadian, kecerdasan, akhlak mulia, serta keterampilan yang diperlukan dirinya, masyarakat, bangsa dan negara.

Pengenalan dan pengembangan budaya daerah melalui pendidikan diarahkan untuk menunjang peningkatan kualitas SDM khususnya kompetensi peserta didik (Ferdianto dan Rusman, 2018). Siswa diberikan kompetensi kognitif, afektif, dan psikomotor lebih sistematis dan sistemik, sehingga melalui pendidikan pemerintah berupaya menyiapkan SDM yang unggul sesuai tuntutan zaman, tetapi tidak melupakan akar budayanya karena kearifan lokal merupakan nilai - nilai luhur yang berlaku dalam tata kehidupan masyarakat, untuk melindungi dan mengelola lingkungan 


\section{Edutainment: Jurnal Ilmu Pendidikan dan Kependidikan}

Volume 8 Nomor 1 Edisi Januari - Juni 2020

hidup secara lestari (UU RI No. 32/2009 pasal 1 ayat 30 ).

Kearifan lokal merupakan tatanan sosial budaya dalam bentuk pengetahuan, norma, peraturan dan keterampilan masyarakat di suatu wilayah untuk memenuhi kebutuhan (hidup) bersama yang diwariskan secara turun menurun. Kearifan lokal juga merupakan upaya yang dilakukan manusia untuk mengangkat potensi atau keunggulan lokal yang dimiliki oleh daerahnya dalam rangka pelestarian lingkungannya (Hidayati, 2016).

Pemerintah berupaya mengangkat kearifan lokal melalui muatan kedaerahan yang dikenal dengan nama muatan lokal (mulok) yang tertuang dalam Pasal 37 ayat 1 Undang - Undang Sistem Pendidikan Nasional dan dipertegas dengan Peraturan Menteri Pendidikan Nasional No. 22 (2006) tentang standar isi untuk satuan Pendidikan Dasar dan Menengah menyatakan bahwa salah satu dari tiga komponen wajib dalam struktur kurikulum yaitu muatan lokal, selain mata pelajaran dan pengembangan diri.

Muatan lokal diajarkan dengan tujuan membekali peserta didik dengan sikap, pengetahuan, dan keterampilan yang diperlukan untuk: a) mengenal dan mencintai lingkungan alam, sosial, budaya, dan spiritual didaerahnya; dan b) melestarikan dan mengembangkan keunggulan dan kearifan daerah yang berguna bagi diri dan lingkungannya dalam rangka menunjang pembangunan nasional. Melalui Mulok, daerah dapat berkontribusi untuk mengangkat potensi wilayahnya, sehingga dapat berkiprah dalam pembangunan nasional. Di bawah otonomi daerah, diharapkan agar sistem pendidikan dan muatan kurikulum pendidikan di daerah senantiasa memperhatikan kebutuhan masing - masing daerah (Wirantho, 2008). Hal ini juga didukung prinsip diversifikasi kurikulum sesuai dengan satuan pendidikan, potensi daerah, dan peserta didik (Pasal 36, ayat 2 Undang - Undang tentang Sistem Pendidikan Nasional). Diversifikasi kurikulum memungkinkan daerah bahkan sekolah menjawab kebutuhan dan tuntutan zaman terkait dengan pelaksanaan otonomi pendidikan di daerah. Lebih jauh, Pemerintahan Daerah berwenang untuk mengatur penetapan kurikulum muatan lokal pendidikan menengah dan muatan lokal pendidikan khusus (lampiran Undang Undang Republik Indonesia No. 23 tahun 2014).

Meskipun demikian, belum banyak daerah yang terpanggil dan memikirkan muatan daerah untuk menjadi bagian dari kurikulum yang sedang dijalankan. Padahal, 


\section{Edutainment: Jurnal Ilmu Pendidikan dan Kependidikan}

Volume 8 Nomor 1 Edisi Januari - Juni 2020

hasil penelitian Andrian

menunjukkan bahwa keberhasilan penerapan mulok membutuhkan dukungan pemerintah lokal, dukungan masyarakat setempat, dukungan industri lokal, dukungan komunitas akademik, minat siswa, motivasi siswa, dan kebutuhan materi praktik. Hasil penelitian ini memperlihatkan pentingnya sinergi dukungan pemerintah, masyarakat, dan siswa dalam pengembangan kearifan lokal. Kebijakan pemerintah daerah yang sesuai dengan muatan lokal di sekolah akan memberi hasil positif (Ferdianto dan Rusman, 2018).

Hasil positif dalam mulok akan terlihat pada keterlibatan siswa. Penelitian dari Ferdianto dan Rusman (2018) juga menunjukkan bawa mulok memberikan ruang bagi setiap perbedaan. Perbedaan minat dan bakat dari peserta didik, keunikan dan potensi dari masing-masing daerah membuat mulok menjadi wadah bagi peserta didik untuk mengembangkan minat dan bakatnya sesuai dengan potensi masingmasing daerah, tidak terkecuali anak berkebutuhan khusus (ABK) agar mereka juga dapat memperoleh pengetahuan dan keterampilan mengenai potensi daerahnya.

Sama dengan anak pada umumnya, ABK juga harus memperoleh layanan pendidikan sejak usia dini hingga pendidikan lanjutan. Undang - Undang No. 20 (2003) tentang Sistem Pendidikan Nasional pada pasal 5 ayat 2 menyatakan bahwa warga negara yang memiliki kelainan fisik, emosional, mental, intelektual, dan/atau sosial berhak memperoleh pendidikan khusus. Selanjutnya, Permendiknas no. 70 tahun 2009 tentang Pendidikan Inklusif memberikan kesempatan kepada semua peserta didik yang memiliki kelainan dan memiliki potensi kecerdasan dan/atau bakat istimewa untuk mengikuti pendidikan atau pembelajaran dalam satu lingkungan pendidikan secara bersama - sama dengan peserta didik pada umumnya. Dengan kata lain, keberadaan ABK telah diakui oleh pemerintah, bahkan negara menjamin hak setiap warganya untuk mendapatkan pendidikan.

Bagi satuan pendidikan, mengimplementasikan Permendikbud no. 79 tahun 2014 tentang Muatan Lokal bukan hal yang mudah. Muatan pembelajaran terkait muatan lokal dapat diintegrasikan antara lain dalam mata pelajaran seni budaya, prakarya, dan/atau pendidikan jasmani, olahraga, dan kesehatan. Namun, jika pengintegrasian tidak dapat dilakukan, muatan pembelajaran terkait muatan lokal dapat dijadikan mata pelajaran yang berdiri sendiri. Sayangnya, masih banyak satuan pendidikan yang 
menempatkan mulok sebagai tuntutan struktur kurikulum tanpa memahami esensinya, sehingga terkesan hanya sebagai formalitas semata. Banyak satuan pendidikan yang terjebak dan menganggap mulok identik dengan bahasa daerah atau bahasa Inggris. Padahal, ruang lingkup mulok mencakup seni budaya, prakarya, PJOK, dan teknologi (Permendikbud no. 79, 2014).

Lebih lanjut, yang juga perlu ditelaah adalah implementasi mulok di satuan pendidikan khusus. Dengan tuntutan yang sama dengan satuan pendidikan yang lain tetapi dengan tantangan yang berbeda, gambaran implementasi mulok di satuan pendidikan khusus akan memberikan masukan bagi pemerintah daerah agar dapat memaksimalkan potensi ABK dalam memahami akar budaya dan potensi daerahnya.

Karena itu, penulisan karya ilmiah akan menjawab pertanyaan penelitian: Bagaimana implementasi mulok untuk Pendidikan Khusus di Provinsi Kepulauan Bangka Belitung.

\section{METODE PENELITIAN}

Penelitian ini menggunakan metode kombinasi kuantitatif dan kualitatif untuk mendapatkan jawaban yang jauh lebih komprehensif. Pengumpulan data kuantitatif dilakukan dengan survei dan pengumpulan data kualitatif dilakukan dengan (1) observasi, (2) Focus Group Discussion (FGD). Proses analisis data secara kualitatif dengan: 1) data - reduction, 2) data display dan conclusion, 3) drawing/verification.

Responden penelitian yaitu 22 guru mewakili sembilan kabupaten/kota dari Provinsi Kepulauan Bangka Belitung, yakni 1) Kota Pangkalpinang, 2) Kabupaten Sungai Liat, Kabupaten Belitung, Kabupaten Belitung Timur, Kabupaten Bangka Tengah, Kabupaten Bangka, Kabupaten Bangka Selatan, dan Kabupaten Bangka Barat.

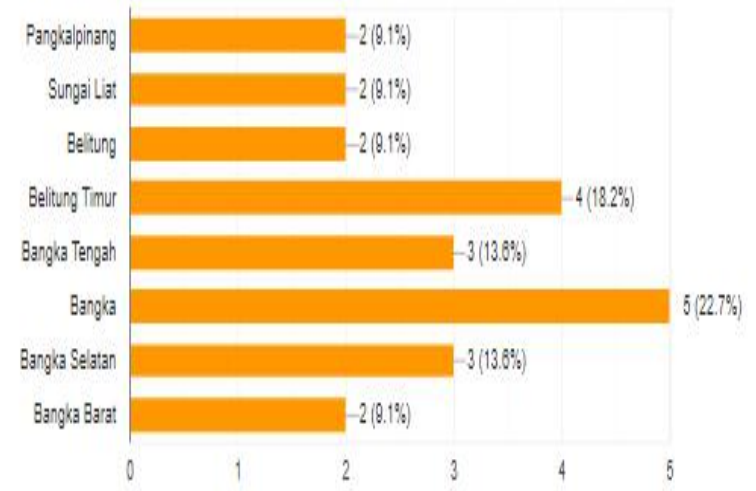

Responden dalam penelitian ini yaitu guru SLB negeri berjumlah 19 orang dan 3 orang dari SLB swasta dengan rincian sebagai berikut: 


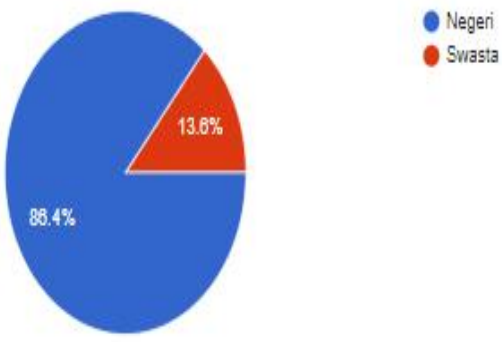

Kebanyakan responden dalam penelitian ini merupakan guru SLB dilihat dengan pengalaman mengajar di atas satu tahun sampai 15 tahun.
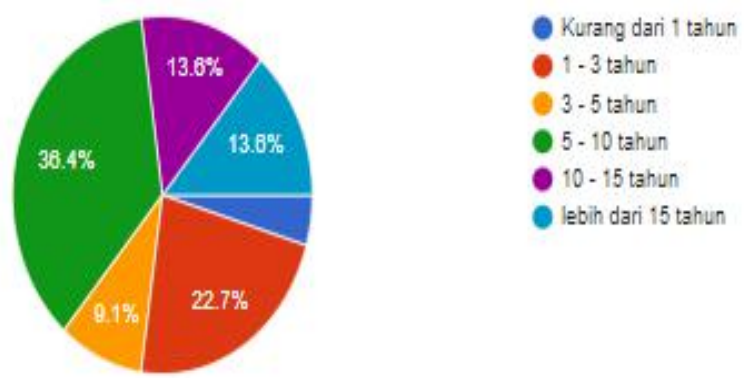

\section{HASIL DAN PEMBAHASAN}

\section{Kedudukan Mulok di Kurikulum 2013}

Provinsi Bangka Belitung melalui Peraturan Gubernur Kepulauan Bangka Belitung, Peraturan Daerah Provinsi Kepulauan Bangka Belitung No. 4 (2016) tentang Pengelolaan dan Penyelenggaraan Pendidikan. Dalam pasal 6 ayat 1 butir $b$ dinyatakan bahwa kewenangan pemerintah provinsi salah satunya yaitu penetapan kurikulum muatan lokal pendidikan menengah dan muatan lokal pendidikan khusus. Dalam pasal 19 ayat 1 tertulis bahwa Pemerintah daerah menetapkan standar penyelenggaraan pendidikan berbasis kearifan dan keunggulan lokal dengan memperhatikan standar nasional pendidikan sebagai media transformasi budaya pada setiap satuan pendidikan. Selain itu, dalam ayat 8 juga dinyatakan bahwa pemerintah daerah menyiapkan sumber daya manusia pendidik yang berkompeten mengajarkan muatan lokal. Lebih lanjut dalam pasal 20 ayat 1 diuraikan bahwa pemerintah daerah harus menyediakan materi kelokalan kurikulum.

Persentase hasil responden sebagian besar menyatakan Mulok di Kurikulum 13 berdiri sendiri menjadi mata pelajaran. Hal ini ditunjukkan dengan tabel sebagai berikut:

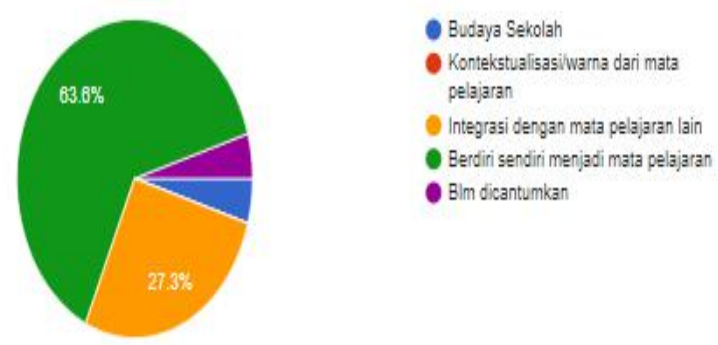

Hal ini disebabkan beberapa alasan, seperti: a) alokasi jam tersendiri, b) mencakup seluruh aspek, c) wawasan/spesifik dan atau bahasan/materi kekhasan daerah, d) dapat dilaksanakan secara optimal, e) identitas daerah/ciri khas agar lebih dikenal.

Mulok berdiri sendiri menjadi mata pelajaran merupakan salah satu bukti perwujudan kepedulian tinggi dari pemangku kepentingan Provinsi Kepulauan Bangka Belitung cq Dinas Pendidikan, 


\section{Edutainment: Jurnal Ilmu Pendidikan dan Kependidikan}

Volume 8 Nomor 1 Edisi Januari - Juni 2020

khususnya Pendidikan Khusus. Mengapa? kedudukan Mulok di struktur kurikulum tidak lagi berdiri sendiri menjadi mata pelajaran, karena tidak memiliki alokasi waktu.

Pada kurikulum 13, Mulok terintegrasi ke dalam Seni Budaya dan Prakarya, Bahasa, dan PJOK, sehingga dapat dinyatakan bahwa Pemerintah Daerah, Dinas Pendidikan, dan tenaga pendidik di Pendidikan Khusus memiliki kepedulian untuk menggali dan mengembangkan Mulok sebagai mata pelajaran.

Pendidik di SLB menerima Mulok sebagai mata pelajaran dengan konsekuensi tidak berharap ada gaji/pembayaran khusus sebagai guru Mulok dan masuk Dapodik, karena Mulok yang dapat masuk Dapodik hanya pada Kurikulum 2006 dan yang memenuhi syarat dan ketentuan yang berlaku, diantaranya ada: a) Peraturan Gubernur, b) Perangkat kurikulum (KI dan KD, Silabus dan RPP, bahan ajar yang sudah dinilai Pusat Perbukuan, c) SDM sebagai guru Mulok, d) LPTK yang sudah meluluskan.

Perkembangan pada kurikulum berikutnya. Meskipun Mulok tidak masuk dalam struktur kurikulum, beberapa daerah yang mengajukan Mulok sebagai mata pelajaran, Kemendikbud (Puskurbuk) sangat merespon positif dengan menerima arahan/bimbingan langsung maupun tak langsung bagi daerah yang ingin menjadikan Mulok sebagai mata pelajaran, kemudian memberikan bimbingan dan arahan dalam mengembangkan perangkat kurikulum Mulok.

Responden sebagian besar (20 orang atau 90,9\%) menyatakan Mulok memiliki kedudukan penting dalam Kurikulum 13, karena: a) mengenal keanekaragaman seni budaya lokal dan keberagaman potensi wisata, kesenian, budaya daerahnya; b) perpaduan pengetahuan dan keterampilan sesuai potensi lokal dan kemampuan aktual di setiap daerah; c) dibekali kompetensi sikap, pengetahuan, dan keterampilan terhadap keunggulan/kearifan daerahnya agar tetap lestari.

Ketiga kompetensi ini akan memotivasi siswa untuk lebih mencintai dan melestarikan kearifan lokal. Implikasi ini membawa konsekuensi agar guru dan orang tua/orang dewasa yang mendampinginya terlebih dahulu memahami materi - materi Mulok.

Pemberian Mulok menurut responden bertujuan untuk: a) mengenal, mengangkat dan melestarikan kearifan lokal dan potensi daerah sebagai identitas diri; b) menanamkan rasa cinta tanah air melalui 
pelestarian kearifan lokal; c) menyiapkan ABK memiliki wawasan, sikap, dan perilaku agar dapat melestarikan dan mengembangkan SDA; dan d) meningkatkan kualitas sosial dan kebudayaan yang mendukung pembangunan nasional pembangunan setempat.

Para responden menyatakan bahwa Mulok penting diberikan di Pendidikan Khusus, karena mulok merupakan: a) media memperkenalkan budaya, menjaga kearifan lokal, dan mengembangkan potensi daerah; b) sarana membuka peluang meningkatkan keterampilan dan berwirausaha; dan c) wahana memupuk rasa cinta dan meningkatkan kualitas diri dan social, sehingga dapat mandiri dan secara tidak langsung dapat berkontribusi dalam pembangunan.

Hasil penelitian menunjukkan bahwa pada dasarnya kehadiran Mulok di satuan pendidikan merupakan sesuatu yang disadari dan dianggap penting untuk dilaksanakan di Pendidikan Khusus. Meskipun belum ada panduan pelaksanaannya, silabus, RPP, dan materi ajarnya. Provinsi Bangka Belitung memiliki keanekaragaman sumber daya alam dan budaya (akulturasi Melayu, Mandarin, dan Jawa). Keanekaragaman ini penting untuk dipahami oleh semua anak termasuk ABK, terlebih lagi di Provinsi
Kepulauan Bangka Belitung yang telah mendeklarasikan diri sebagai provinsi penyelenggara pendidikan inklusi sejak 2015. Karena itu, dinas pendidikan dan satuan pendidikan memiliki tanggung jawab moral untuk memfasilitasi ABK memperoleh layanan pendidikan yang sama.

Para responden menyatakan materi Mulok di satuan pendidikan khusus SAMA dengan satuan pendidikan lainnya. Hal ini dapat diwujudkan sesuai dengan ruang lingkup muatan lokal yang terdiri atas: seni budaya, prakarya, PJOK, bahasa, dan teknologi. Dengan rincian: a) Seni budaya diantaranya yaitu lagu daerah, rumah adat, adat istiadat daerah, tari daerah (tari campak, tari dambus, tari sambut), kesenian dambus (tari, lagu, instrumen, pakaian), dan jenis wisata. Dengan demikian, siswa mengenal seni budaya, sehingga siswa dapat meniru, melakukan, dan menunjukkan/menyajikannya melalui lisan atau media dua atau tiga dimensi. Dengan seni budaya diharapkan dapat menumbuhkan kecintaan pada kesenian tradisional daerahnya. Seni Budaya juga dapat melatih kemampuan motorik halus dan kasar dalam menari, memainkan alat musik, dan wisata daerah dengan mengoptimalkan indera yang ada. b) Prakarya diantaranya yaitu kerajinan khas (batik cual, anyaman, pewter), 


\section{Edutainment: Jurnal Ilmu Pendidikan dan Kependidikan}

Volume 8 Nomor 1 Edisi Januari - Juni 2020

minuman khas, jenis masakan khas, dan jenis kue khas.

Pengetahuan yang akan didapat peserta didik yaitu mengenal bahan dan alat dengan gambar, benda tiruan, benda asli. Terkait kompetensi afektif, pengenalan prakarya menumbuhkan kecintaan pada kerajinan dan kuliner khas daerah. Dari sisi kompetensi psikomotor, prakarya melatih kemampuan motorik halus dan kasar dalam membuat kerajinan dan kuliner dengan mengoptimalkan indera yang ada, sehingga siswa mampu berwirausaha. c) $P J O K$ diantaranya yaitu permainan (sembunyi sembunyian/gong, hadang/ sembilun, cak lingking, cungkil/patok lele/kepala ayam/anak ela, batu tujuh, celetosan/senjetop/su'ter, juai gerebok, gasing, lubang batok, bola tampah, kereta sorong. Ada beberapa jenis permainan yang sama bentuk permainannya tetapi berbeda nama dengan permainan di daerah lain.

Kompetensi kognitif, pengenalan jenis, aturan, sarana prasarana, dan barang yang dibutuhkan di permainan dengan pendampingan guru/ahli/pendamping. Dari sisi kompetensi afektif, pengenalan permainan daerah menumbuhkan kecintaan pada permainan tradisional dan menumbuhkan rasa kebersamaan dan sportivitas. Dari sisi kompetensi psikomotor, permainan - permainan ini melatih kemampuan motorik halus dan kasar dengan mengoptimalkan indera yang ada dengan pendampingan guru/ahlinya. d) bahasa di antaranya yaitu bahasa daerah, pantun dan peribahasa daerah, gurindam 21, cerita rakyat. Terkait kompetensi kognitif, pengenalan secara berulang dengan cara meniru agar anak mampu dan terbiasa diucapkan dalam kehidupan sehari -hari.

Dari kompetensi afektif, pengenalan bahasa menumbuhkan kecintaan pada bahasa, pantun, peribahasa, gurindam 21, cerita rakyat. Pada kompetensi psikomotor, berbagai seni yang terkait bahasa ini melatih kemampuan dengan mengoptimalkan indera untuk menampilkan bahasa, pantun, peribahasa, gurindam 21, dan cerita rakyat dalam bentuk lisan maupun tulisan. e) teknologi diantaranya yaitu alat penangkap udang (cerucup dan sungkur/sungkor), alat penangkap ikan (injap/bubu), lesong, sistem pengairan bebak, teknik nyulo, dan siro. Kompetensi kognitif dari teknologi tradisional diperkenalkan dengan menggunakan gambar, tiruan, dan barang aslinya dengan pendampingan guru/ahlinya. Selain itu, pada kompetensi afektif, pengenalan teknologi tradisional menumbuhkan kecintaan pada produk budaya khas daerah. Kemudian, pada 
kompetensi psikomotor, teknologi tradisional melatih kemampuan motorik halus dan kasar dalam membuat dan menggunakan dengan mengoptimalkan indera yang ada dengan tepat guna dalam kehidupan sehari - hari. Berdasarkan hasil observasi, dalam proses pembuatan pewter ABK harus didampingi oleh guru pendamping/tenaga pendamping. Faktor keselamatan kerja juga harus menjadi perhatian utama, diantaranya menggunakan sarung tangan, tang penjepit, masker.

Guru mensiasati kedalaman, dan cakupannya mengingat karakteristik dan kondisi ABK yang bervariasi yang memerlukan pendekatan khusus dan bimbingan. Kompetensi Mulok untuk ABK dapat difokuskan pada aspek kognitif, psikomotorik, sikap, dan kemandirian.

\section{SIMPULAN DAN SARAN}

Pengembangan Kurikulum Mulok di Pendidikan Khusus penting dilakukan untuk meningkatkan pengetahuan, sikap, dan keterampilan sesuai

potensi/kearifan/keunggulan Provinsi

Kepulauan Bangka Belitung. Muatan lokal ini berdiri sendiri menjadi mata pelajaran. Ruang lingkupnya yaitu: seni budaya, prakarya, PJOK, bahasa, dan teknologi.

Mulok ini bertujuan 1) meningkatkan pengetahuan tentang kekhasan daerah berupa seni budaya, prakarya, PJOK, bahasa, dan teknologi, 2) menumbuhkan rasa mencintai dan melestarikannya, bersikap dan berperilaku untuk percaya diri, mandiri, bekerja sama, disiplin, dan bertanggung jawab, 3) membiasakan melakukan dalam kehidupan sehari - hari di lingkungan sekolah, rumah, dan masyarakat, 4) memberikan bekal keterampilan untuk berwirausaha.

Pengembangan Kurikulum Mulok tidak sebatas penyusunan kompetensi dasar (KD) berdasar ruang lingkup seni budaya, prakarya, PJOK, bahasa, dan teknologi. Namun perlu ditindaklanjuti dengan pembuatan silabus, RPP, dan bahan ajar untuk pendidik dan peserta didik.

Pengembangan Mulok memerlukan proses panjang dengan mengacu pada analisis konteks dari daerah dan satuan pendidikan sehingga dalam diperlukan keterlibatan dan dukungan dari berbagai pihak dalam pengembangannya, diantaranya dari Pemerintah daerah khususnya Dinas Pendidikan dan narasumber (budayawan, penutur asli bahasa lokal, dinas pariwisata, pelaku seni, ahli kurikulum, psikologi perkembangan).

Disediakan ruang khusus untuk
pembuatan prakarya agar dapat
meminimalisir kecelakaan kerja.


Dalam pembelajaran pendidik dapat mendatangkan narasumber yang kompeten dibidangnya. Dapat mengundang orang tua/pekerja seni/lainnya yang punya keahlian tertentu.

Kemampuan berbahasa daerah bagi guru bukan asli dari Bangka Belitung dapat berguru pada teman/penutur asli, sehingga akan memudahkan dalam pembelajaran dan menjadi kebiasaan dalam berkomunikasi.

Untuk permainan guru harus membangkitkan kembali kenangan ketika bermain pada masa kecil. Jika tidak tahu, guru diharapkan mencari tahu.

\section{DAFTAR PUSTAKA}

Andrian, D. (2019). Developing an instrument to evaluate the influential factors of the success of local curriculum. REiD (Research and Evaluation in Education). 5(1). 75-84 diunduh dari http://journal.uny.ac.id/index.php/reid

Ferdianto, V. B. dan Rusman. (2018). Evaluasi implementasi kurikulum muatan lokal bahasa daerah dan pendidikan lingkungan hidup. Jurnal penelitian ilmu pendidikan. 11 (2). UNY. Hidayati, D. (2016). Memudarnya Nilai Kearifan Lokal Masyarakat dalam Pengelolaan Sumber Daya Air. Jurnal Kependudukan Indonesia, Vol. 11 No. 1 Juni 2016, 39-48. Jakarta.

Undang - Undang No. 20. (2003). Sistem Pendidikan Nasional. Jakarta: Inspektorat Jenderal Departemen Pendidikan Nasional.

Undang - Undang Republik Indonesia No. 32. (2009). Perlindungan dan Pengelolaan Lingkungan Hidup. Jakarta:
Inspektorat Jenderal Departemen Pendidikan Nasional.

Undang - Undang Republik Indonesia No. 23. (2014). Pemerintahan Daerah. Jakarta: Inspektorat Jenderal Departemen Pendidikan Nasional.

Peraturan Menteri Pendidikan Nasional No. 22. (2006). Standar Isi untuk Satuan Pendidikan Dasar dan Menengah. Jakarta: Inspektorat Jenderal Departemen Pendidikan Nasional.

Peraturan Menteri Pendidikan Nasional Republik Indonesia No. 70. (2009). Pendidikan Inklusif bagi Peserta Didik yang Memiliki Kelainan dan Memiliki Potensi Kecerdasan dan/atau Bakat Istimewa. Jakarta: Inspektorat Jenderal Departemen Pendidikan Nasional.

Peraturan Menteri Pendidikan dan Kebudayaan no. 79. (2014). Muatan Lokal Kurikulum 2013. Jakarta: Inspektorat Jenderal Departemen Pendidikan Nasional.

Peraturan Gubernur Kepulauan Bangka Belitung Peraturan Daerah Provinsi Kepulauan Bangka Belitung No. 4. (2016). Pengelolaan dan Penyelenggaraan Pendidikan. Jakarta: Inspektorat Jenderal Departemen Pendidikan Nasional.

Wirantho, Sapto Aji. http://kabarmadura05.blogspot.com/200 8/11/bahasa-madura-masuk-pelajaransekolah.html? $\mathrm{m}=1$ diakses pada tanggal 11 Februari 2020 pukul 18.33 WIB 